\title{
One-to-one tutoring and mathematics students' achievement in the United Arab Emirates
}

\author{
Barry J. Fraser \\ Curtin University, Australia \\ Abeer A. Hasan \\ Higher Colleges of Technology, UAE
}

\begin{abstract}
In this study in the United Arab Emirates (UAE), we investigated college students' perceptions of their past experience of receiving one-to-one tutoring support in mathematics when they were in secondary school. In addition, we also explored students' reasons for taking one-to-one tutoring in mathematics, the perceived impact of one-to-one tutoring in overcoming shortcomings of school mathematics teaching and on their mathematics achievement, and whether the learning environment at school influenced decisions about having one-to-one tutoring. Eight case-study students were involved in recalling how beneficial one-to-one tutoring was through semi-structured interviews. Because of the small sample size, the research involved only qualitative data based on the recollections of college students who were attending a one-year course in the General Education department of Abu Dhabi Men's College. The research provided valuable insights into how some students considered having a one-to-one tutor beneficial for their achievement when they were in secondary school. Educators must consider students' learning environment as being one of the main reasons for deciding whether or not to undertake one-to-one tutoring to raise their achievement in mathematics.
\end{abstract}

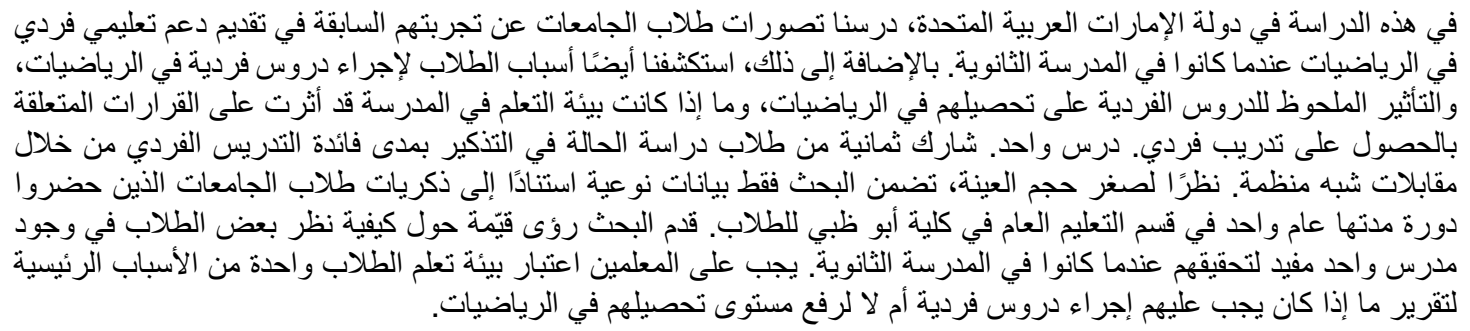

\section{Introduction}

We investigated the effectiveness of one-to-one tutors for Emirati students who had been low achievers in mathematics at secondary school in terms of whether it raised their grades. It has been noted with concern, in the UAE, that poor-quality instruction exists in some schools and that teaching methods typically are based on rote memorisation (Gaad, Arif \& Scott, 2006; Shaw, Badri \& Hukul, 1995). According to an article in the Khaleej Times (2010), there is very little research in the UAE into $\mathrm{K}-12$ teaching practices that can lead to enhanced learning outcomes among students. Innovation on the part of teachers is often viewed as difficult because of the demands of complying with a centralised curriculum and evaluation system that is enforced by administrators and school inspectors. Explanation and discussion are the most common teaching methods, with little use of small-group, individualized, experimental, laboratory or role-playing methods. Furthermore, the Gulf News (2011) (a UAE newspaper) claimed that the current system does not help students to develop a level of creativity and that the teaching style is based on authoritarian and memory techniques that do not support a flexible economy and a world based on knowledge.

To overcome these problems, UAE's Ministry of Education (MoE) has developed an Education 2020 strategy, which is a series of ambitious five-year plans designed to bring significant qualitative improvement in the education system, especially in the way that teachers teach and students learn.

Fraser, B.J. \& Hasan, A. (2019). One-to-one tutoring and mathematics students' achievement in the United Arab Emirates. Learning and Teaching in Higher Education: Gulf Perspectives, 16(1). 
Smart learning programmes, new teachers' licensing and evaluations methods, and curriculum revision, including teaching mathematics and science through English, are all part of the strategy (Khaleej Times, 2018).

More importantly, there also has been a substantial move away from factual recall and memorisation to developing higher-order thinking skills and nurturing students' creativity and critical thinking. This is likely to enhance students' resilience, adaptability, interpersonal skills, level of communication and problem-solving ability, which are described as the basics of numeracy, literacy and IT skills (Khaleej Times, 2018).

Eight male college students, all of whom currently were studying higher-education mathematics at the time of our study and had attended Abu Dhabi secondary schools, comprised individual case studies in this research. These eight students volunteered to be case studies during the 2016 academic year. Variation across the cases was achieved by including students with a range of ages, grades and experience in mathematics to offer more-convincing interpretations and reinforce the trustworthiness of findings. One-to-one tutoring helped students to make important decisions about which method they find best for obtaining correct answers and enhancing their achievement in mathematics.

The overarching aim of the present study was to investigate the effectiveness of one-to-one tutoring in compensating for low-quality school mathematics teaching and improving mathematics school students' achievement in the UAE. The following research questions helped to address this aim:

1. Why did school students in the UAE undertake one-to-one tutoring in mathematics?

2. What was the impact of one-to-one tutoring on mathematics students' achievement?

3. Did the school learning environment influence students' decisions to have one-to-one tutoring?

\section{One-to-one tutoring}

Foodun (2002) defined private tutoring as extra and remunerated coaching in academic and examinable subjects that is given to the students outside school hours. Tutoring can be at the teacher's home, pupils' homes, school premises or private tutoring centres. A competent tutor is a person who diagnoses and discovers the causes of a student's inability to learn in the classroom (Gordon, 2003) and who routinely improves student academic performance and increases students' self-efficacy (Linden, 2013). Oyewusi and Orolade (2014) noted that, because some academically-weak students gain little from the classroom, they seek the help of a private tutor whom they believe will raise their academic achievement.

By offering systematic, structured learning experiences in a more individualized way, tutoring can improve the tutee's self-esteem, attitude towards subject matter, academic performance and personal growth. In addition, tutoring is a self-paced and self-directed learning process (Schmid College of Science and Technology, 2016). Effective tutoring is likely to help tutees to become independent learners, acquire critical learning skills, and learn how to help themselves. This procedure is likely to have a positive impact on students' social and physical well-being because they need to spend less time studying (Farah, 2011).

Effective mathematics tutoring should demonstrate during each tutoring session how learning mathematics occurs in general. The role of the tutor is not to show how to solve a mathematics problem, but to help tutees learn how to find answers and solutions on their own. While guiding students through the process of tutoring, tutors should discuss the process that allows students to find their own solutions (Schmid College of Science and Technology, 2016). 
There is a significant difference in the benefits for students between classroom instruction and oneon-one tutoring sessions. School teachers have to adapt their teaching to a group of students with many different backgrounds, learning styles and interests. While students stated that teachers do extremely well at one of the toughest jobs, students who receive one-on-one tutoring have their needs accommodated and can make leaps and bounds academically (Study Hut Tutoring, 2011). Because many students have a difficult time studying subjects that seem irrelevant to them, it can be beneficial to have a tutor who relates to them personally. Having a tutor to whom they can relate to helps students understand that, if their tutor feels the need to know something, maybe they should know it also.

One-on-one tutoring also allows the teaching method to cater for a student's particular learning style. Some students are visual learners, who need charts and diagrams of concepts to really grasp them, while others need repetition to help them retain information. Some students benefit from undertaking more sample problems and being able to ask questions throughout the practice.

Tutors can really get to know their students, their interests, their families and events going on in their lives, all which affect their academic progress. Tutors can understand students' aspirations, stress with which they are dealing, and who they are outside the classroom. All these factors have a positive impact of students' academic achievements (Study Hut Tutoring, 2011).

Casazza and Silverman (2013) claim that studies of the effects of tutoring on student success demonstrate a significant trend: the more academic support the students receive, the more likely they are to pass their courses and stay enrolled. Therefore, one-to-one tutoring can help students grasp the subject in ways that are most beneficial to them.

\section{Background to this study}

This research involved a sample of 28-34 year-old students currently attending the Higher Colleges of Technology (HCT), Abu Dhabi, where the first author is a part-time lecturer in mathematics to low achievers who had encountered difficulty in learning mathematics and had one-to-one tutors when they were at school. The small number of students in eight college classes (varying between 10 to 15 students in each class and a total of 94 students) were asked whether they needed one-to-one teaching when they attended secondary school, whether it had a positive impact on their achievement, and whether it built their confidence about their mathematics skills.

\section{Education in the UAE}

When comparing the education system of the UAE with systems of education in other countries, its history is relatively short. Prior to the 1950s, home schooling was common and great emphasis was placed on religious studies (Kamal, 2018). At that time, education generally included studying the Holy Quran, writing, arithmetic and Arabic calligraphy. Bradshaw et al. (2004) reported that, in 1952, public schooling officially began, an academic authority was established to oversee the national curriculum, and subjects in addition to religious studies were included into the education system.

The United Arab Emirates Ministry of Education (MOE) was established by the UAE government after the Declaration of Federation of the Seven Emirates in 1971 to take responsibility for both the public and private schools that operate within the seven emirates (Gaad, Arif \& Scott, 2006). For the public school system, the MoE assumes a broad set of roles that are similar to those of Ministries of Education in other countries: buildings and infrastructure; hiring staff; determining educational standards; providing curriculum materials; and ensuring that adequate programs are operating (Bradshaw, Lydiatt \& Tennant, 2004). 
For private schools, the Ministry for Education oversees licensure and assumes more of a supervisory role. It ensures that the basic requirements of schools are met, including the physical components of the site and the appropriateness of educational programs.

Within each emirate, an Education Council ensures that the educational quality within private and public educational institutions (including early learning centres, training institutions and universities) is up to standard. The Abu Dhabi Education Council (ADEC) is an independent corporate body which was established by Sheikh Khalifa to work closely with the MoE in formulating the Emirate's education plan within the framework of the UAE's general education policy (UAE Interact, 2011). Federal public schools (including kindergartens) are free of fees for UAE citizens, easily accessible are well distributed geographically.

The Department of Education and Knowledge (ADEK), previously known as Abu Dhabi Education Council, was established in 2005 to develop education and educational institutions in the Emirate of Abu Dhabi, implement innovative educational policies, plans and programs for improving education, and support educational institutions and staff in achieving the objectives of national development in accordance with the highest international standards (ADEK, 2019).

\section{Mathematics education in the UAE}

In 2006, the UAE's Ministry of Higher Education and Scientific Research (MOHESR) launched the Common Educational Proficiency Assessment (CEPA) examination in mathematics in order to determine whether students require a foundation year to strengthen their mathematics skills before enrolling in the UAE's major public higher education institutions (MOHESR, 2010). In 2017, the MoE announced that CEPA would be replaced by the computer-based Emirates Standardized Test (EmSAT), which was administered to public school students in Grades 1, 4, 6, 8, 10 and 12 in the 2017-18 academic year (Pennington, 2017). Sahoo (2016) noted that the MoE often partners with foreign companies to design curriculum content (e.g. the seven-year arrangement in 2016 between the MoE and McGraw-Hill Education to develop mathematics and science curricula).

Tarazi (2016) found that students in the UAE are still performing poorly in mathematics in middle and high schools despite the efforts of educational leaders to improve mathematics curricula. Results of international testing for the Trends in International Mathematics and Science Study (TIMSS) indicated that the average mathematics achievement of fourth and eighth grade students in the UAE was below the TIMSS scale centre point of 500 (Muillis, Martin, Foy \& Arora, 2011).

The Program for International Student Assessment (PISA) in 2012 revealed that the UAE was below average according to the Organisation for Economic Cooperation and Development (OECD, 2015-16). Consequently, identifying a continuous need for improvement, education leaders in the UAE are instigating and monitoring high-quality educational standards by starting new policies, programs and initiatives (Tarazi, 2016). The National Assessment of Educational Progress revealed that students' scores had not improved meaningfully in mathematics between 1990 and 2009 (NAEP, 2009).

\section{Factors influencing decisions to undertake one-to-one tutoring}

Clarity, organisation (planning, sequencing, clarifying and assessing instruction), motivation and the learning environment are the main factors that drive students to decide to have one-to-one tutoring in mathematics. Comadena, Hunt and Simonds (2007) reported that teacher clarity has a positive and significant relationship with students' achievement, attitudes towards the teacher and course, and cognitive development.

Past studies suggest that both school climate and student motivation consistently relate to academic achievement (Caraway, Tucker, Reinke \& Hall, 2003; Gilman \& Anderman, 2006; Gustafsson \& Nilsen, 2016; Hardre \& Reeve, 2003; Roeser \& Eccles, 1998; Scherer \& Nilsen, 2016; Stewart, 2008). Wolf and

Fraser, B.J. \& Hasan, A. (2019). One-to-one tutoring and mathematics students' achievement in the United Arab 
Fraser (2007) reported that students' classroom environment perceptions were closely related to their learning outcomes, including achievement.

Titsworth (2004) suggests that giving students the opportunity to take notes from lectures can have a positive impact on their learning from the lecture. While there is a range of behaviours related to high teacher clarity, studies on this topic in various disciplines point to the importance of communicating subject matter to students in a way that makes it intelligible and thus enables their learning. These relationships reinforce the importance and the interconnectedness of teaching skills in planning, organising, sequencing, clarifying and assessing instruction.

Research by Badri (2018) suggests that teachers are a significant influence on students' achievement. Clarifying what the teacher requires students to learn from the information presented in lectures is vital for student learning because it provides an outline or list of questions or problems to be focused on during class. Presenting and explaining course material clearly and concisely can help students to more effectively process and retain course content (Nilson, 2010). Because lesson goals explain what students need to understand and be able to do, they help the teacher to plan learning activities and students to understand what is required (Hattie, 2009).

Lessons should be structured to start with a warm-up exercise to remind students about the topic that was completed in the previous lesson in order to identify what skills students already have mastered, because teachers should not assume that students know or remember concepts and terms from prior courses (Nuhfer \& Knipp, 2003). In this way, teachers can pinpoint students' weaknesses and go over them again in order to ensure that the topic is completely understood by most of the class. It is helpful to students if the teacher focusses on three to five main points. Because repetition leads to learning, it is useful to repeat major concepts for a topic several times using different vocabulary or with different examples.

Kyriakides, Christoforou and Charalambous (2013) found that the way in which teachers structure lessons impacts on student learning and achievement. Apparently student achievement can be improved when teachers structure lessons so that they start with an overview of objectives, outline the learning objectives to be covered, signal transitions between lesson parts, draw attention to main ideas, and summarize the main ideas at the end of a lesson.

Consolidation can involve asking students to test their understanding. This can be accomplished by interrupting the class session every 10 or 15 minutes to ask students to work with the concept or idea presented by solving a problem and generating questions or related examples. Summarising key points about a topic can take place at the end of lectures by asking students questions in order to guide the teacher concerning what parts of the topic need to be stressed during the next lecture (Cameron, 2002).

\section{Research methods}

\section{Participants}

This study involved the perceptions about secondary-school tutoring held by students who were attending a course with a mathematics component in Abu Dhabi Men's college in the UAE. There were 10 to 15 students, aged between 28 and 34 years, in each of eight classes. Eight of the 94 students volunteered to be case studies. One student from each of the eight classes was chosen to provide a range of ages. Case studies were used to investigate complex phenomena within the context of mathematics classes (Baxter \& Jack, 2008). Because of the small sample size, only qualitative data collection involving semi-structured interviews was used. 
The eight case-study students were aged $28,29,30,31,32,33,34$ and 34 years and each had attended a different school in Abu Dhabi. Some of the case-study students were confident and verbally skilful, which maximised the chances of obtaining rich information and insightful comments (Patton, 1990).

During the five months prior to the research, the establishment of strong teacher-student relationships at the college made students more willing to recollect their school experiences and compare them with their current college lessons. A sense of mutual trust and regular contact with students during the time leading up to the research facilitated data collection.

\section{Procedures}

As mentioned above, the research was mainly qualitative in nature and involved collecting data using a variety of methods, especially interviews.

\section{Semi-structured interviews}

Eight male students agreed to interviews that took place at the HCT and involved a semi-structured approach. As suggested by Creswell (2009), a fixed set of questions was used to direct the interviews in order to achieve a degree of reliability and flexibility across all interviews. The interviews sought students' views about why they required one-to-one support in their school mathematics, whether the support was perceived to improve their achievement in mathematics, and if the learning environment of the classroom (Fraser, 2018) affected their results. An initial interview was conducted with the case-study participants individually during week one of the semester. The purpose of this interview was to obtain background information about participants, identify their previous experience in mathematics, find out their perceptions of their achievement when they had a one-to-one tutor when they were at school, and ascertain whether the learning environment influenced their achievement. The same interview protocol was followed for all participants and written notes were taken during these interviews. A copy of this initial interview protocol can be found in Appendix A.

\section{Thematic analysis}

Thematic analysis (Aronson, 1994) was used to identify all data that related to already-classified patterns, which were then expounded upon. For example, case-study students expressed their reactions to the one-to-one tutoring that they had received in the past. Sub-themes were identified to obtain a comprehensive overview of the information and to identify emerging patterns. As patterns emerged, follow-up was sought from the case-study students through interviews or by asking them to give feedback on the transcribed conversations. The students' feedback was often used to develop the next questions in the interview.

To build a valid argument, we then returned to the related literature to make inferences from the interviews (Aronson, 1994). It was important to develop a storyline to help the reader to comprehend the process and to understand and motivate the case-study students. This involved weaving the findings with the literature and formulating themes.

The data analysis was guided by a framework which involved following three stages suggested by Pope, Ziebland and Mays (2000):

Familiarisation. Once the interviews were transcribed, immersion in the raw data enabled familiarisation with the information collected. A brainstorm of initial key themes was undertaken to allow the grouping of ideas.

Indexing. The interview documents were carefully re-read and each quote that represented an experience, issue, need, conflict or strategy was highlighted and assigned a colour. Different colours represented different themes. 
Charting. Once all of the interviews were colour-coded, each coloured quote was collated into individual themed documents. The most poignant quotes were included in summary charts, which then provided distilled summaries of the views, experiences and perceptions of participants. The final stage of the analysis was the inclusion of participant recommendations.

\section{Focus-group interviews}

The focus-group interview is commonly used to gain detailed perceptions of what, how and why strategies are found to be acceptable and feasible (Bartholomew, Parcel, Kok, Gottlieb \& Fernández, 2011). Interviews were appropriate for use in this study because interactions between the participants were likely to yield more in-depth information. In addition, this type of interview was useful because the amount of time available for collecting information was limited and the individuals were likely to be hesitant about providing data (Creswell, 2005).

Robinson (1999) stated that the use of qualitative interviews in a group format has several advantages, which include gaining relevant underlying insights, perceptions and assumptions; detecting subtle ambiguities which are hard to identify using quantitative methods; and having a group dynamic which can minimise the impact of extreme views, help to assess the degree to which there is a consistent and shared view, and enable social norms and beliefs to be traced.

Focus-group interviews involved all participants in our research. During each interview, a small number of general questions were asked about how the one-to-one teaching contributed to their achievement in mathematics. Responses were elicited from all individuals in the group and notes were made of the students' answers. A copy of this interview protocol can be found in Appendix B.

\section{Discourse analysis for semi-structured interviews}

Traditionally, language has been regarded as a static entity, composed of component parts, produced by a communicator and decoded by a listener or reader. In contrast, discourse analysts reject the notion of language as an unambiguous series of signs, but consider language as being engaged actively in meaning-making (Wetherell, 2001). When people state a belief or express an opinion, they are taking part in a conversation which has a purpose and in which all participants have a stake. In other words, to make sense of what people say, we need to take into account the social context within which they speak (Willig, 2003). This form of analysis involves examining how specific discourses are formed (Silverman, 2000). Selected text from the interviews for each of the eight case-study students was examined to demonstrate how it was organised rhetorically, in order to make claims as persuasive as possible, and warranted by the data (Billig, 1996).

\section{Results}

The qualitative data indicated that, when they were at school, students generally had experienced poorly-structured mathematics lessons, low clarity of teachers' explanation and directions, and had played a very passive role. However, students claimed that having a one-to-one tutor compensated for these shortcomings at school and enhanced their achievement in mathematics. All students interviewed had similar views about the poor quality of teaching during their mathematics classes at school, including not being exposed to different methods to convey concepts, not participating and being involved in the learning process, not being monitored and not having their needs met.

The feedback received from these students indicated that one-to-one tutoring provided them with positive and constructive feedback from the tutor at the end of each lesson. In addition, the tutor made good use of questioning techniques and ensured coverage of all learning objectives. Kyriakides et al. (2013) and Muijs et al. (2014) identified teachers' questioning of students as one of the mostwidely researched aspects of teaching. Effective questions have diverse levels; they can emphasise both product and process and lead to additional information if a student gives a partly-correct answer.

Fraser, B.J. \& Hasan, A. (2019). One-to-one tutoring and mathematics students' achievement in the United Arab 
In contrast, during their school mathematics classes, students were not allowed to air their views about how the lesson had progressed, which was perceived as having a negative impact on their achievement. Therefore, for these reasons, students required one-to-one support.

One of the reasons for having one-to-one tutors is to raise student grades in mathematics and to overcome anxiety which has a negative impact on achievement. Interviews revealed that students required one-to-one tutors to ensure that they understood concepts that they did not grasp during their mathematics lessons at school. Responses to interview questions and associated commentaries highlight these factors.

\section{Factors influencing students' achievement}

\section{Clarity and organisation}

According to a male student who was interviewed, the teacher's instructions and explanations when at school were vague, ambiguous or took no account of students' abilities. Explaining course material clearly and concisely is critical for students' learning, understanding and achievement. Preparation, organisation, clarity and the learning environment have considerable impact on students' achievement (Feldman, 2007; Fraser, 2018; Pascarella; Salisbury \& Blaich, 2011).

Rodger, Murray and Cummings, (2007) have identified specific teaching behaviours that define high teacher clarity and highlight the linkage between teacher clarity and learning. For example, behaviours such as putting an outline on the board or computer projector, signalling transitions between key points, using relevant and multiple examples during explanations, repeating difficult ideas, stressing important points, and reviewing material consistently have a positive influence on student learning outcomes.

Other students claimed that the mathematics that they experienced at school had unclear teacher explanations, directions which did not promote learning, and delivery that was neither well-structured nor well-organised:

Because the teacher's style of explaining the topic was neither clear nor well organised, I focused on copying from the board without understanding what I was copying and how the final answer to the equation was achieved. (Faisal)

The teacher was not sure how he/she wanted the lesson to start or develop or what he/she wanted to do next; materials such as worksheets were not available. (Kareem)

Moreover, students stressed that the teacher neither ensured that instructions were clear and concise nor, where possible, involved a step-by-step outline of what was required. Fogarty (1997) notes that students need clarity about what should be accomplished by the end of the session.

All students whom were interviewed agreed that they were always off task because they felt that the lessons were neither useful nor helpful for learning mathematics through collecting information, writing down facts and hypotheses, and discussing them with their peers or teacher.

\section{Monitoring and involvement}

One student claimed that the teacher neither monitored students' progress nor attended quickly to students' needs. He added that students did not know if they had achieved the correct answer, where they went wrong, or how to obtain the correct answer.

After teachers prepare class notes, they need to review them carefully and ask themselves what students might find hard to follow and what examples might make a concept clearer as recommended by Nuhfer and Knipp (2003). Teachers might highlight the parts of their presentation that students are likely to find difficult and make a special effort to make those points very clear (Cameron, 2002): 
Class interaction did not take place. We were given a class exercise but, because our answers were not corrected, we did not know who solved the problem correctly and this was reflected in failing the monthly examination. (Muhannad)

With respect to involvement, negotiation is a vital aspect of the learning environment because it provides opportunities for students to participate in class discussions, exchange ideas and understand what they learn with one another, rather than just taking notes passively (Fraser, 2012; Taylor \& Campbell-Williams, 1993).

During the interviews, students mentioned that they were not involved in discussions with their colleagues and did not exchange their thoughts throughout their mathematics lessons. For example, one of the students, Husain, was enthusiastic about solving the problem posed in class and finding out from his peers whether they had a simpler or faster way to find the answer, but this was not permitted in class. These finding are supported by Aldridge and Fraser (2008), who reported that social acceptance by peers and the need to have friends are important aspects that can affect students' learning and achievement. In addition, class discussions lead to effective learning and high achievement because they have the potential to enhance students' goal setting, self-monitoring, selfquestioning and self-checking (Montague, 2004).

Another student remarked:

The teacher never asked for my opinion. I was not involved in dialogue during the whole lessons. I was wondering what it feels like when I explained my ideas to the whole class and other learners asked me questions about how I solved the problem. (Abdulla)

\section{Learning environment}

In an effective classroom learning environment, the teacher's authority to organise and manage learning activities is accepted by students, there is mutual respect, good rapport, good class control and management, and purposefulness and confidence in learning. Kareem stated:

I did not feel that the teacher showed any respect to my attendance in class because I was ignored when I asked a question that referred to the previous lesson but which was related to the present lesson.

\section{Creating positive teacher-student relationships}

Successful tutors build strong, personal relationships with their students, listen and communicate in a respectful way with students and have specific content expertise (Linden, 2013). Muhannad's comments below suggests good rapport between the students and the tutor, including mutual respect and openness. He cast his mind back to feeling nervous and afraid at school in case the teacher asked him a question for which he gave a wrong answer or did not know the answer. He always knew that the consequence would involve being criticised:

I wished I could gain a degree of trust and mutual respect from my teacher, which I did not, because this would have provided me with a feeling that I was in a relaxed atmosphere in which I would feel confident to ask questions and where my teacher generated a positive relationship with me during the course as being approachable, encouraging and helpful.

Teachers, either inside or outside the classroom, exert a great deal of influence on establishing highquality teacher-student relationship (Barry \& King, 1999). In such an emotional climate, the most important ingredients of effective teaching for teachers are maintaining and improving a positive relationship with students and providing materials to cater for students' needs and interests (Jones \& Jones, 2004). Students' deeper understanding can be achieved through dialogue and collaboration with their peers and their teachers (Biggs, 1999).

According to Barry and King (1999), the quality of the teacher's relationship with students is largely decided by the quantity and quality of contact made with each student as an individual. A good

Fraser, B.J. \& Hasan, A. (2019). One-to-one tutoring and mathematics students' achievement in the United Arab 
teacher treats students as individuals, has a loving heart and is warm to his/her students. Teachers' socioemotional and instructional support has been found to relate positively to students' academic achievement, particularly to normed achievement measures rather than grades, and socio-emotional outcomes including self-efficacy, interest in class, and prosocial behaviours and goals (Rolland, 2012).

School connection is the belief by students that adults in the school care about their learning and about them as individuals. Students are more likely to succeed when they feel connected to school. Critical requirements for feeling connected include high academic rigour and expectations, support for learning, positive teacher-student relationships and physical and emotional safety (Blum, 2005).

The teacher plays a significant role in creating a relaxed learning environment during the learning process by providing mutual respect and trust with students as recommended by Chodkiewicz, Widin and Yasukawa (2010). According to Perry (2006), the relationships that educators establish between themselves and students and among students in a class are important for creating the best learning environment. Furthermore, Aldridge and Fraser (2008) claim that a supportive learning environment permits students to make mistakes without the risk of being ridiculed:

I would have felt relaxed if I saw the teacher moving around the classroom and stopping to talk to me even if I did not put my hand up to request help. This would have made me feel that the teacher was interested in supporting me and that she/he considered my feelings. If I needed to ask a question, I would never feel that I would be accused of not listening or humiliated in front of the class.

\section{Developing a supportive environment through collaboration}

Education Endowment Foundation (2015) suggests that collaboration occurs when students work together in small groups and everyone participates in a learning task. Based on what they had experienced at school, students described a supportive environment as involving collaboration, talking to each other, asking questions, helping each other work out problems, and comparing and sharing with each other. They also wished that the teacher ensured that collaboration took place at least during some lessons. By comparing and sharing answers with each other, students collaborated and were encouraged to interact and communicate. Collaborative learning relies on students actively participating in negotiating roles, responsibilities and outcomes (Education Endowment Foundation, 2015).

This was in strict contrast to anything that students had experienced before in their past school education. As one of the students stated: "I felt that the teacher looked at me as a piece of furniture and not as a human being who has feelings" (Abdulla, aged 24 years). According to Barry and King (1999), students are humans first and learners second. The school should not only be an institution for teachers to enhance students' learning, but also an interactive community of human beings:

I am enthusiastic about solving problems that are given and airing my view about the steps that I took to achieve the answer. Also, I am eager to find out whether my friends have a simpler method that I might use in solving the problem in the future. This is the first time that I have been given the opportunity to share.

Collaborative learning in mathematics classrooms develops a community in which students can provide emotional and intellectual support for each other. This collaborative work promotes discussion of alternative strategies and makes mathematics learning an engaging and interactive process, with the teacher not necessarily being the source of all information as recommended by Steinke (2008). It appears that collaboration had an impact on students' self-esteem, confidence and motivation, leading to improved student achievement as stated by Salem (aged 22 years). Motivation is a central component of education. In fact, school-based administrators and teachers reported that motivation is one of the most important determinants of student achievement (Education Week Research Center, 2014). 


\section{Conclusion}

In this study in the UAE, we explored higher-education students' recollections of shortcomings in their secondary-school mathematics and how one-on-one tutoring overcame these, especially in terms of students' perceived achievement. Our research was richly descriptive, allowing students during semistructured interviews to express their views and experiences about one-to-one tutoring compared with their school mathematics classes. Responses to interview questions revealed that students were enthusiastic about their one-to-one lessons because the teacher motivated them and raised their confidence, found the lesson interesting, understood the topic through experiencing an organised a relaxed atmosphere, and found the lessons useful for their achievement in mathematics. Motivation for learning is one of the most influential factors that affect performance in school (Griffin, MacKewn, Moser, \& VanVuren, 2012).

Our research is significant because it is one of the first studies of the effectiveness of one-to-one tutoring in terms of mathematics students' perceived achievement in the UAE. Moreover, this study adds to our understanding of factors that influence students to undertake one-to-one tutoring in a context focusing on mathematics achievement within the classroom (e.g. Chionh \& Fraser, 2009; Dorman, 2001; Kilgour, 2006; Majeed et al., 2002; Mink \& Fraser, 2005; Moldavan, 2007; Ogbuehi \& Fraser, 2007; Spinner \& Fraser, 2005). Our study potentially could contribute to the development of the education system in the UAE and the standard of teaching in mathematics classroom.

An educator's enthusiasm to integrate a variety of teaching techniques into lessons is a key to success in enhancing student achievement in mathematics. However, some teachers find it difficult to use techniques that are different from the ones that they have been using for years. It is hoped that the results of the present study might persuade mathematics educators to employ more innovative pedagogical practices that can encourage and engage students in the learning process through using a variety of techniques. Teaching methods that involve creating positive teacher-student relationships and supportive learning environments involving collaboration, clarity and organisation provide students with experience in exploration and experimentation (Khine \& Saleh, 2009). Ellerbrock and Kiefer (2010) reported that trusting, caring and respectful relationships between students and teachers provide emotional and cognitive support and are crucial for student development and achievement. In addition, researchers draw attention to the potential of new teaching techniques for promoting collaboration, competencies and participation (Kirriemuir \& McFarlane, 2004). Khine and Saleh (2009) advocate that the task that lies ahead for educators is to draw on teaching techniques to modify traditional approaches into new learning models. This involves using new methods and strategies such as clarity and organisation, monitoring, involvement and providing a healthy working environment. Researchers have found that positive learning environments affect students' motivation for learning (Genc, 2009; Kazu \& Demirkol, 2014; Rosen, 2009) and they recommend that educators capitalise on the motivational power of a more-relaxed learning environment.

\section{References}

ADEK. (2019). Ministry of Education and Knowledge. Retrieved February 24, 2019, from https://www.adek.abudhabi.ae/en/AboutADEC/Pages/default.aspx

Aldridge, J. M., \& Fraser, B. J. (2008). Outcomes-focused learning environments: Determinants and effects (Advances in Learning Environments Research series). Rotterdam, the Netherlands: Sense Publishers.

Aronson, J. (1994). A pragmatic view of thematic analysis. The Qualitative Report, 2, 1-3.

Badri, M. (2018). School emphasis on academic success and TIMSS science/math achievements. International Journal of Research in Education and Science, 5, 176-189. 
Barry, K., \& King, L. (1999). Beginning teaching and beyond (3rd ed.). Sydney, Australia: Social Science Press.

Bartholomew, L. K., Parcel, G. S., Kok, G., Gottlieb, N. H., \& Fernández, M. E. (2011). Planning health promotion programs: An intervention mapping approach (3rd ed). San Francisco: Jossey Bass.

Baxter, P., \& Jack, S. (2008). Qualitative case study methodology: Study design and implementation for novice researchers. The Qualitative Report, 13, 544-559.

Biggs, J. (1999). What the student does. Higher Education Research \& Development, 18, 57-75.

Billig, M. (1996). Arguing and thinking: A rhetorical approach to social psychology ( $2^{\text {nd }}$ ed.). Cambridge, MA: Cambridge University Press.

Blum, R. (2005). School connectedness: Improving the lives of students. Baltimore, MD: Johns Hopkins Bloomberg School of Public Health.

Bradshaw, K., Tenant, L., \& Lydiatt, S. (2004). Special education in the United Arab Emirates: Anxieties, attitudes and aspirations. International Journal of Special Education, 19(1), 49-55.

Comadena, M.E., Hunt, S.K., \& Simonds, C.J. (2007). The effects of teacher clarity, nonverbal immediacy, and caring on student motivation, affective and cognitive learning. Communication Research Reports, 24(3), 241-248.

Cameron, L. (2002). Metaphors in the learning of science: A discourse focus. British Educational Research Journal, 28(5), 673-688.

Caraway, K., Tucker, C. M., Reinke, W. M., \& Hall, C. (2003). Self-efficacy, goal orientation, and fear of failure as predictors of school engagement in high school students. Psychology in Schools, 40, 417427. doi: 10.1002/pits.10092

Casazza, M., \& Silverman, S. (2013). Meaningful access and support - The path to college completion. Boone, NC: Council of Learning Assistance and Developmental Education Associations, p. 15

Chionh, Y. H., \& Fraser, B. J. (2009). Classroom environment, achievement, attitudes and self-esteem in geography and mathematics in Singapore. International Research in Geographical and Environmental Education, 18, 29-44.

Chodkiewicz, A., Widen J., \& Yasukawa, K. (2010). Making connections to re-engage young people in learning: Dimensions of practice. Literacy and Numeracy Studies, 18, 35-51.

Creswell, J. (2009). Research design: Qualitative, quantitative and mixed approaches. Thousand Oaks, CA: Sage Publications.

Cultural Division of the Embassy of the United Arab Emirates. (2011). Education in the UAE. Retrieved June 18, 2019 from http://www.uaecd.org/k-12-education

Dorman, J. P. (2001). Associations between classroom environment and academic efficacy. Learning Environments Research, 4, 243-257.

Dorman, J. P., \& Fraser, B. J. (2009). Psychological environment and affective outcomes in technologyrich classrooms: Testing a causal model. Social Psychology of Education, 12, 77-99.

Education Endowment Foundation. (2015). Collaborative learning. Retrieved May 16, 2019, from https://educationendowmentfoundation.org.uk/evidence-summaries/teaching-learning-

toolkit/collaborative-learning.

Education Week Research. (2014). Motivation. Retrieved June 24, 2019, from https://k12engagement.unl.edu/strategy-briefs/Motivation\%203-15-15_1.pdf 
Ellerbrock, C. R., \& Kiefer, S. M. (2010). Creating a ninth-grade community of care. The Journal of Educational Research, 103, 393-406. doi:10.1080/00220670903383085

Farah, S. (2011). Private tutoring trends in the UA, Dubai School of Government Policy Brief, 26, 1-8.

Feldman, K. A. (2007). Identifying exemplary teachers and teaching: Evidence from student ratings. In R. P. Perry \& J. C. Smart (Eds.), The scholarship of teaching and learning in higher education: An evidence-based perspective (pp. 93-143). Dordrecht, The Netherlands: Springer.

Fogarty, R. (1997). Problem-based learning and other curriculum models for the multiple intelligences classroom. Upper Saddle River, NJ: Skylight Professional Development.

Foondun, A. R. (2002). The issue of private tuition: An Analysis of the practice in Mauritius and selected South-East Asian Countries. International Review of Education 48, 485-515.

Fraser, B. J. (2012). Classroom learning environments: Retrospect, context and prospect. In B. J. Fraser, K. G. Tobin \& C. J. McRobbie (Eds.), Second international handbook of science education (pp. 11911239). New York: Springer.

Fraser, B. J. (2018). Milestones in the evolution of the learning environments field over the past three decades. In D. B. Zandvleit and B. J. Fraser (Eds.), Thirty years of learning environments research: Looking back and looking forward (pp. 1-19). Rotterdam: Brill-Sense.

Gaad, E., Arif, M., \& Scott, F. (2006). Systems analysis of the UAE education system. International Journal of Educational Management, 20, 291- 303.

Genc, I. B. (2009). Effect of technology on motivation in EFL classrooms. Turkish Online Journal of Distance Education, 10, 136-158.

Gilman, R., \& Anderman, E. M. (2006). The relationship between relative levels of motivation and intrapersonal, interpersonal, and academic functioning among older adolescents. Journal of School Psychology, 44, 375-391. doi: 10.1016/j.jsp.2006.03.004

Gordon, E.E. (2003). Looking beyond the stereo types: Ensuring the true potential of tutoring. Phi Delta Kappan, 84, 456-459.

Griffin, R., MacKewn, A., Moser, E., \& VanVuren, K. W. (2012). Do learning and study skills affect academic performance? - An empirical investigation. Contemporary Issues in Education Research. 5, 109-116.

Gulfnews. (2011, October 4). UAE education. Retrieved May 4, 2012, from http://gulfnews.com/news/gulf/uae/education/traditional-teaching-style-needs-revamp

Gustafsson, J. E., \& Nilsen, T. (2016). The impact of school climate and teacher quality on mathematics achievement: A difference-in-differences approach. In J. E. Gustafsson, \& T. Nilsen (Ed.), Teacher quality, instructional quality and student outcomes (pp. 81-95). New York: Springer.

Hardre, P. L., \& Reeve, J. (2003). A motivational model of rural students' intentions to persist in, versus drop out of, high school. Journal of Educational Psychology, 95, 347-356. doi: 10.1037/00220663.95.2.347

Hattie, J. (2009). Visible learning: A synthesis of over 800 meta-analyses relating to achievement. Milton Park, UK: Routledge.

Jones, V., \& Jones, L. (2004). Comprehensive classroom management: Creating communities of support and solving problems $\left(7^{\text {th }}\right.$ ed.). Boston: Allyn \& Bacon.

Kamal, K. (2018). Education in the United Arab Emirates. Retrieved June 18, 2019, from https://wenr.wes.org/2018/08/education-in-the-united-arab-emirates 
Kazu, Y. I., \& Demirkol, M. (2014). Effect of blended learning environment model on high school students' academic achievement. Turkish Online Journal of Educational Technology, 13, 78-87.

Khaleej Times. (February 09, 2010). Education: What's the right teaching method? Retrieved May 4, 2019, from

http://www.khaleejtimes.com/uaeedufocus.asp?xfile=/data/education/2010/February/education_F ebruary2.xml\&section=education

Khaleej Times. (April 15, 2018). Education in the UAE: Then, now and tomorrow. Retrieved June 15, 2019, from https://www.khaleejtimes.com/kt-40-anniversary/education-in-the-uae-then-now-andtomorrow

Khine, M. S., \& Saleh, I. H. (2009). Gameplay habits among middle school students: A descriptive study. Journal of Educational Technology Systems, 34, 431-440.

Kilgour, P. W. (2006). Student, teacher and parent perceptions of classroom environment in streamed and unstreamed mathematics classrooms. Unpublished doctoral thesis, Curtin University of Technology, Perth.

Kirriemuir, J., \& McFarlane, A. (2004). Literature review in games and learning. Bristol, UK: Futurelab.

Kyriakides, L., Christoforou, C. \& Charalambous, C. (2013). What matters for student learning outcomes: A meta-analysis of studies exploring factors of effective teaching. Teaching and Teacher Education, 36, 143-52.

Linden, S. (2013, October 11). What makes a successful tutor? Retrieved May 28, 2019, from https://www.edutopia.org/blog/what-makes-a-successful-tutor-seth-linden

Majeed, A., Fraser, B. J., \& Aldridge, J. M. (2002). Learning environment and its association with student satisfaction among mathematics students in Brunei Darussalam. Learning Environments Research, 5, 203-226.

Mink, D. V., \& Fraser, B. J. (2005). Evaluation of a K-5 mathematics program which integrates children's literature: Classroom environment and attitudes. International Journal of Science and Mathematics Education, 3, 59-85.

Ministry of Higher Education and Scientific Research (MOHSER). (2010). NAPO newsletter. Retrieved June 20, 2019 from http://www.uaecd.org/ministry-higher-education-and-scientific-research-mohesr

Montague, M. (2004). Math problem solving for middle school students with disabilities. Retrieved November 21, 2011, from the Access centre Website.

Muijs, D., Kyriakides, L., van der Werf, G., Creemers, B., Timperley, H., \& Earl, L. (2014). School effectiveness and school improvement: State of the art. Teacher Effectiveness and Professional Learning: An International Journal of Research Policy and Practice, 25, 231-256.

Mullis, I. V. S., Martin, M. O., Foy, P., \& Arora, A. (2011). TIMSS 2011 international results in mathematics. Amsterdam: International Association for the Evaluation of Educational Achievement.

NAEP. (2009, October). The Nation's Report Card. Retrieved June 22, 2019, from https://nces.ed.gov/nationsreportcard/pdf/main2009/2010451.pdf

Nilson, L. (2010). Teaching at its best: A research-based resource for college instructors (3rd ed.). San Francisco: Jossey-Bass.

Nuhfer, E., \& Knipp, D. (2003). The knowledge survey: A tool for all reasons. In C. Wehlburg \& S. Chadwick-Blossey (Eds.), To improve the academy, 21 (pp. 59-78). Bolton, MA: Anker Publications.

OECD. (2015-16). PISA worldwide ranking - Average score of maths, science and reading. Paris: OECD. 
Ogbuehi, P. I., \& Fraser, B. J. (2007). Learning environment, attitudes and conceptual development associated with innovative strategies in middle-school mathematics. Learning Environments Research, 10, 101-114.

Oyewusi, L. M., \& Orolade, K. S. (2014). Private tutoring boom in Nigeria: An Investigation into the emerging but controversial learning space. Journal of Educational and Social Research, 4, 271-274.

Patton, M. Q (1990). Qualitative evaluation and research methods ( $2^{\text {nd }}$ ed.). Newbury Park, CA: Sage Publications.

Pennington, R. (2017). The National: New exam for Grade 12 pupils in UAE, says Minister of Education. Retrieved July 2, 2019 from http://www.the national.ae/uae/new-exam-for-grade-12-pupils-in-uaesaysminister-of-education

Perry, B. D. (2006). Applying principles of neurodevelopment to clinical work with maltreated and traumatized children: The neurosequential model of therapeutics. In N. Boyd Webb (Ed.), Working with traumatized youth in child welfare (pp. 27-52). New York: Guilford Press.

Pope, C., Ziebland, S., \& Mays, N. (2000). Qualitative research in health care: Analysing qualitative data. British Medical Journal, 320, 114-116.

Robinson, (1999). The use of focus group methodology - with selected examples from sexual health research. Journal of Advanced Nursing, 29, 905-13.

Rodger, S., Murray, H.G., \& Cummings, A.L. (2007). Effects of teacher clarity and student anxiety on student outcomes. Teaching in Higher Education, 12 (1), 91-104.

Roeser, R. W., \& Eccles, J. S. (1998). Adolescents' perceptions of middle school: Relation to longitudinal changes in academic and psychological adjustment. Journal of Research on Adolescence, 8, 123-158.

Rolland, R. G. (2012). Synthesizing the evidence on classroom goal structures in middle and secondary schools: A meta-analysis and narrative review. Review of Educational Research, 82, 396-435.

Rosen, Y. (2009). The effect of an animation-based on-line learning environment on transfer of knowledge and on motivation of science and technology learning. Journal of Educational Computer Research. 40, 451-467.

Scherer, R., and Nilsen, T. (2016). The relations among school climate, instructional quality, and achievement motivation in mathematics. In T. Nilsen and J. E. Gustafsson (Ed.), Teacher quality, instructional quality and student outcomes (pp. 51-80). New York: Springer

Schmid College of Science and Technology. (2016, February 9). What tutoring is and what tutoring is not. Retrieved May 28, 2019 from

https://blogs.chapman.edu/scst/2016/02/09/what-tutoring-is-and-what-tutoring-is-not/

Shaw, K. E., Badri, A. A., \& Hukul, A. (1995). Management concerns in the United Arab Emirates state school. International Journal of Educational Management, 9, 8-13.

Silverman, D. (2000). Doing qualitative research: A practical handbook. London: Sage.

Spinner, H., \& Fraser, B. J. (2005). Evaluation of an innovative mathematics program in terms of classroom environment, student attitudes, and conceptual development. International Journal of Science and Mathematics Education, 3, 267-293.

Steinke, D. (2008). Focus of basics: Using part-whole thinking in maths. Connecting Research and Practice, 9, 1-49.

Study Hut Tutoring. (2011, September). The importance of one-on-one tutoring. Retrieved June 9, 2019, from https://studyhut.com/tag/benefits-of-one-on-one-tutoring/ 
Tarazi, N. (2016). The influence of the inverted classroom on student achievement and motivation for learning in secondary mathematics in the United Arab Emirates: A quasi-experimental. Unpublished doctoral dissertation, Northcentral University.

Taylor, P. C., \& Campbell-Williams, M. (1993). Discourse toward balanced rationality in the high school mathematics classroom: Ideas from Habermas's critical theory. In J. A. Malone \& P. C. S. Taylor (Eds.), Constructivist interpretations of teaching and learning mathematics (Proceeding of Topic Group 10 at the Seventh International Congress on Mathematical Education (pp. 135-148). Perth, Western Australia: Curtin University of Technology.

Titsworth, B.S. (2004). Students' notetaking: The effects of teacher immediacy and clarity. Communication Education, 53, 305-320.

UAE Interact. (2012). Education center. Retrieved July 02, 2019, from https://emiratisation.org/education-uae-interact

Wetherell, M. (2001). Debates in discourse research. In M. Wetherell, S. Taylor \& S. J. Yates (Eds.), Discourse theory and practice: A reader (pp. 380-399). London: Sage.

Willig, C. (2003). Discourse analysis. In J. A. Smith (Ed.), Qualitative psychology: A practice guide to research methods (pp. 159-161). London: Sage.

Wolf, S. J., \& Fraser, B. J. (2007). Learning environment, attitudes and achievement among middleschool science students using inquiry-based laboratory activities. Research in Science Education, 38, 321-341. 


\section{Appendix A}

\section{Case study questions}

First-week interview questions

1. Tell me about yourself.

Do you have siblings? If so, what are their ages? Which grades are they in?

Are you married?

Do you have children? If so, what are their ages? Which grades are they in?

2. Did you have a one-to-one tutor when you were at school? If so, at which grade/grades?

3. Do any of your siblings or children have a one-to-one tutor now? If so, how many of them have a tutor and at which grades?

Fraser, B.J. \& Hasan, A. (2019). One-to-one tutoring and mathematics students' achievement in the United Arab Emirates. Learning and Teaching in Higher Education: Gulf Perspectives, 16(1). 


\title{
Appendix B
}

\section{Weekly interview questions for the case study}

\author{
Semi-structured interviews
}

1. What made you decide to have a one-to-one tutor in mathematics when you were at school?

2. Did the one-to-one tutor raise your standards in mathematics? Did it have a positive impact on your achievement?

3. What were the main factors that made you decide that you required a one-to-one tutor to improve your achievements?

4. Did the learning environment of your mathematics class have a negative impact on your achievement in the subject? 